\title{
Bird species diversity captured by protected areas in the Andes of Colombia: a gap analysis
}

\author{
Padu Franco, Carlos A. Saavedra-Rodríguez and Gustavo H. Kattan
}

\begin{abstract}
Formed by three Andean ranges and two peripheral elements, the complex mountainous system of Colombia harbours a diverse avifauna ( $>1,500$ spp.) characterized by high large-scale beta diversity and endemism. In these mountains there are 25 protected areas covering $c$. 3.5 million hectares but not all ecosystems are adequately represented. We conducted an analysis of representation of bird species in these protected areas for eight subregions of the Colombian mountains by means of a comparison between potential and recorded faunas in each area. Potential faunas were compiled by considering the distribution of species across the subregions, their elevational ranges, and the elevational extent covered by each protected area in each subregion. Analyses were performed separately for all species and for migrant species, with an emphasis on threatened species. Bird inventories are lacking for nine of the protected areas. Existing inventories have representation values of $4-91 \%$ for all species, and
\end{abstract}

$3-72 \%$ for migrant species. Assuming that all potential species occur within protected areas, representation values for the subregions were high (74-100\%) but may be as low as $26 \%$ when representation values are estimated using recorded species only. For most Andean subregions representation decreased with decreasing elevation, revealing a lack of protected areas at lower elevations. In addition, 31 threatened species (26\% of total), which mainly occur at lower elevations and in adjacent lowlands, are not covered by protected areas. Thus, although birds are relatively well protected by the system of reserves in the mountains of Colombia, significant gaps remain, particularly for threatened species.

Keywords Andes, beta diversity, birds, Colombia, mountains, protected areas.

This paper contains supplementary material that can only be found online at http://journals.cambridge.org

\section{Introduction}

A prominent feature of north-western South America's geography is the mountainous system of Colombia, which is formed by three Andean ranges, the Sierra Nevada de Santa Marta and Serranía de La Macarena (Fig. 1). The northern Andean region has been highlighted in global biodiversity assessments for its high levels of biodiversity, threat and endemism (McNeely et al., 1990; Stattersfield et al., 1998; Myers et al., 2000; Orme et al., 2005). More than 1,500 bird species occur in these mountain systems, representing almost $84 \%$ of Colombia's and $15 \%$ of the world's species. The complex physiography of the northern Andes has given rise to high large-scale beta diversity, or turnover in species composition, among slopes in the different mountain

Padu Franco (Corresponding author), Carlos A. Saavedra-Rodríguez ${ }^{*}$ and Gustavo H. Kattan Fundación EcoAndina/Wildlife Conservation Society Colombia Program, Apartado Aéreo 25527, Cali, Colombia.

E-mail padufranco@telesat.com.co

*Also at: Departamento de Biología, Universidad del Valle, Cali, Colombia.

Received 23 June 2005. Revision requested 18 October 2005

Accepted 30 March 2006. ranges (Kattan et al., 2004). Even within a given Andean slope, beta diversity is high because of species turnover among elevational zones and watersheds (Kattan \& Franco, 2004; Kattan et al., 2006). Thus, although species richness decreases with elevation and alpha (i.e. local) diversities are low in the Andes, gamma or regional diversity is high. Neotropical montane systems have diverse and unique avifaunas with many restricted range species (Bibby et al., 1992; Renjifo et al., 1997).

Colombia has 50 protected areas in the various categories of the National System of Protected Areas, administered by the National Parks Unit under the Ministry of the Environment. These protected areas cover c. 10.4 million hectares, but $66 \%$ of this area is in lowland ecosystems in Amazonia, the Orinoco basin, the Chocoan lowlands and the Caribbean plains. Half of the reserves cover montane ecosystems, but comprise only 3.5 million hectares.

An important goal of reserve systems is obtaining representation of the regional diversity of ecosystems, communities and species (Groves, 2003). All these components of biodiversity must be considered independently when planning reserves because focusing on a single component does not guarantee protection of 


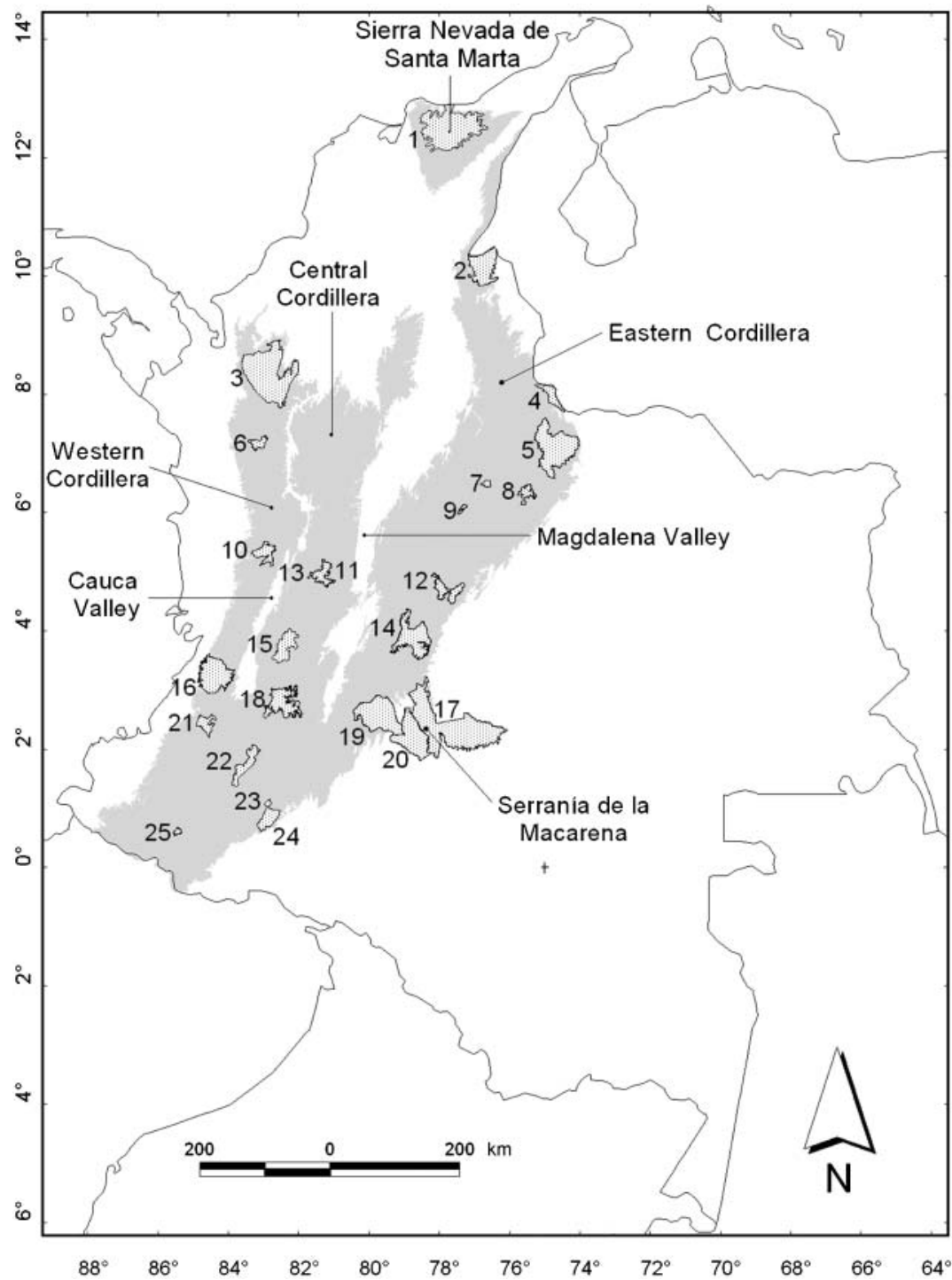

Fig. 1 Colombia showing the Andean region and the National Natural Parks (PNN) and Flora and Fauna Sanctuaries (SFF): 1, PNN Sierra Nevada de Santa Marta; 2, PNN Catatumbo Barí; 3, PNN Paramillo; 4, PNN Tamá; 5, PNN El Cocuy; 6, PNN Las Orquídeas; 7, SFF Guanentá Alto Río Fonce; 8, PNN Pisba; 9 , SFF Iguaque; 10, PNN Tatamá; 11, PNN Los Nevados; 12, PNN Chingaza; 13, SFF Otún Quimbaya; 14, PNN Sumapaz; 15, PNN Las Hermosas; 16, PNN Farallones de Cali; 17, PNN Sierra de la Macarena; 18, PNN Nevado del Huila; 19, PNN Cordillera de los Picachos; 20, PNN Tinigua; 21, PNN Munchique; 22, PNN Puracé; 23, PNN Cueva de los Guácharos; 24, PNN Alto Fragua Indi Wasi; 25, SFF Galeras. other components (Bonn \& Gaston, 2005). In many cases reserves have been established at different times, following idiosyncratic criteria and needs (Pressey, 1994). In the case of the Colombian Andes many protected areas were established to protect the headwaters of important river systems. Thus, these reserves only protect the upper elevations, leaving lower slopes and inter-Andean valleys unrepresented. A recent analysis of representation of mammals, amphibians, freshwater turtles and threatened birds in the global network of protected areas identified the northern Andes as a critical ecoregion (Rodrígues et al., 2004). In Colombia, all the terrestrial biogeographical provinces defined by Hernández-Camacho et al. (1992) are represented in the National Parks System, but at a finer scale many biogeographical districts are not represented (Arango, 1998). Likewise, 20 of the 64 terrestrial ecosystems of Colombia defined by Etter (1998) are not represented in the system (including six Andean ecosystems; Arango et al., 2003).

Here we present an analysis of representation of bird species for eight subregions in the Andean reserve system of Colombia (including Sierra Nevada de Santa Marta and Serranía de La Macarena). We obtained bird inventories for 16 of the 25 protected areas (no inventories were available for the other nine protected areas), and compared them to the potential bird fauna occurring in the subregion based on general geographic distributions, taking into account elevational ranges of species and altitudinal zones covered by reserves. We asked three questions. Firstly, how many of the species potentially occurring in each reserve have actually been recorded in species inventories? As this may reflect not only lack of representation but also lack of knowledge (incomplete inventories), we asked a second question: assuming all potential species occur in the reserves 
(which is unlikely), how many species are unrepresented in each subregion? Thirdly, how many threatened species are represented and in how many reserves?

\section{Study area}

The Andean system of Colombia is formed by three independent ranges with different geological histories (Bürgl, 1961; Irving, 1975); the Western, Central and Eastern mountain chains (Cordilleras), which lie parallel to one other with a south-north orientation (Fig. 1). The Sierra Nevada de Santa Marta is an independent massif rising to high elevations $(>5,000 \mathrm{~m})$ next to the Caribbean coast, north of the Andes. Serranía de La Macarena is a low-rising massif east of the Andes that geologically is part of the Guianan Shield. Based on previous work that revealed differences in species composition among mountain ranges and between east and west slopes of the three Andean ranges (Kattan et al., 2004), we defined eight subregions: Santa Marta, Macarena, and east and west slopes of the three Andean ranges. The two external Andean slopes, i.e. the western slope of the Western Cordillera facing the Pacific Ocean, and the eastern slope of the Eastern Cordillera facing the Orinoco and Amazonian lowlands, have continuity with lowland biotas (see Kattan \& Franco, 2004). The other four slopes form the internal Andean slopes of the Cauca and Magdalena river valleys (Fig. 1).

\section{Methods}

We conducted an extensive literature review to obtain bird lists for all Andean protected areas in two categories: Parque Nacional Natural (National Natural Park; PNN) and Santuario de Flora y Fauna (Flora and Fauna Sanctuary; SFF; Appendix 1). SFF Isla de la Corota was excluded because of its small size ( $8 \mathrm{ha})$, and PNN Tinigua was merged with its neighbouring PNN, Sierra de la Macarena. We compiled a list of potential avifauna for each subregion, based on Hilty \& Brown (1986) and Stotz et al. (1996) and complemented by other published lists, unpublished reports and our personal knowledge. From these lists we produced a list of the potential avifauna of each protected area, taking into account the elevational ranges of the species and the elevational extent covered by each reserve. For reserves straddling mountain ranges and occupying two subregions (e.g. PNN Farallones de Cali, which encompasses both slopes of the Western Cordillera), we analysed each subregion separately. From these lists we obtained the percentage of species for each subregion occurring within protected areas, and then obtained percentages separately for different elevational zones (every $500 \mathrm{~m}$ over $0-3,000 \mathrm{~m}$, and an upper elevational zone above 3,000 m). We made these analyses for all species, and for northern and southern temperate zone migrants separately. In addition, we obtained lists of species at risk (in the Critically Endangered, Endangered, Vulnerable, and Near Threatened categories; IUCN, 2001) from Renjifo et al. (2002), and tallied their representation in the reserve system.

\section{Results}

Overall, $83 \%$ of 1,502 bird species occurring in Colombian montane systems are represented in at least one of the 16 protected areas for which inventories were obtained. This representation, however, varied widely (Fig. 2). The highest representation was found in PNN Sierra Nevada de Santa Marta, where 91\% of species potentially occurring in the Park have been recorded in species inventories. In contrast, in PNN Sierra Nevada del Cocuy only $4 \%$ of species potentially occurring have been recorded. Representation of potential migrant species was $3-72 \%$. In six of the eight subregions the proportion of potential species that has actually been recorded within protected areas was $>50 \%$ (Table 1). Representation on both slopes of the Eastern Cordillera was $<27 \%$. Compared to the Western and Central Cordilleras, this mountain range has the greater number of protected areas and bird species (Appendix 1; Kattan et al., 2004) but few have been well studied (Fig. 2).

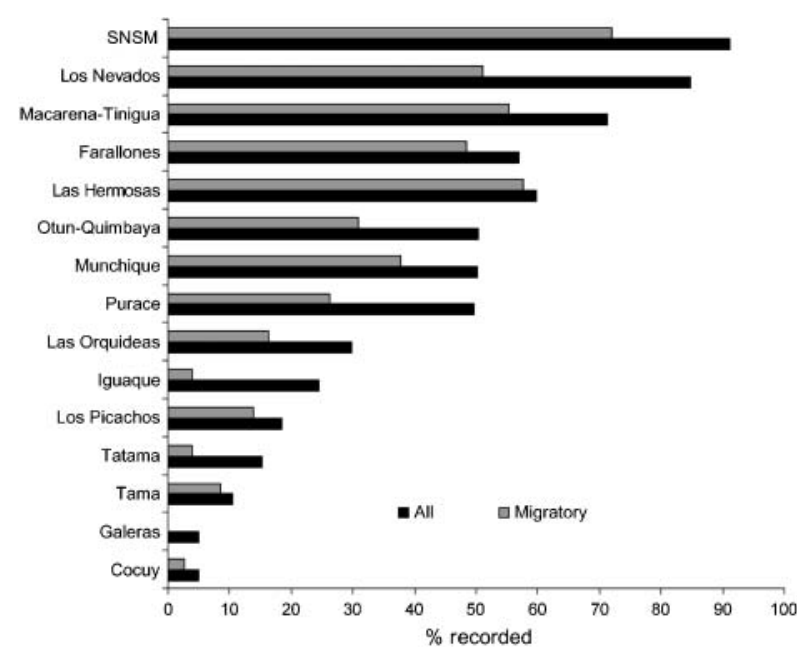

Fig. 2 Percentages of potential bird species (for all and migratory species separately) recorded in 16 protected areas (SNSM, Sierra Nevada de Santa Marta) of the Colombian Andes (see Fig. 1 for locations). PNN Tinigua is merged with PNN Sierra de la Macarena (see text for details). 
Table 1 Representation of potential and recorded bird species in protected areas in eight subregions of the Colombian Andes.

\begin{tabular}{lllll}
\hline Subregion & No. of Parks & Total spp. in subregion & $\begin{array}{l}\text { \% of spp. potentially } \\
\text { occurring in Parks }\end{array}$ & \% of spp. recorded in Parks \\
\hline Western Cordillera & & & & 70.9 \\
$\quad$ W versant & 6 & 851 & 100.0 & 84.1 \\
$\quad$ E versant & 5 & 504 & 94.6 & 75.8 \\
Central Cordillera & 5 & 562 & 87.5 & 59.6 \\
$\quad$ W versant & 4 & 611 & 79.2 & 15.5 \\
$\quad$ E versant & 7 & 682 & 74.5 & 26.5 \\
Eastern Cordillera & 8 & 1087 & 100.0 & 71.3 \\
$\quad$ W versant & 2 & 606 & 100.0 & 91.0 \\
$\quad$ E versant & 1 & 647 & 100.0 & \\
Serranía de la Macarena & & &
\end{tabular}

The percentage of potential species occurring within elevational zones that have actually been recorded in protected areas was uneven among elevational zones and subregions (Table 2). PNN Sierra Nevada de Santa Marta, which covers the entire altitudinal range, has c. $90 \%$ representation in all elevational zones, but only c. $70 \%$ representation of migrants. In contrast, in the internal Andean slopes (i.e. slopes of the Cauca and Magdalena river valleys) representation decreased drastically with decreasing elevation, reflecting the lack of protected areas at lower altitudes. Representation is particularly poor on the Magdalena valley slopes (eastern slope of Central Cordillera and western slope of Eastern Cordillera), even at higher elevations. If all potential species occur within each of the protected areas, representation values for each subregion would be high, reaching $100 \%$ in some cases (Table 1).

Of 152 species classified in a threat category in Colombia (Renjifo et al., 2002), 121 occur in the mountain systems included in this analysis (Appendix 2). Eightyeight of these species are recorded in at least one protected area, but most are represented in less than three (Fig. 3). The other 33 species have not been recorded in any protected area, but eight are potentially present in at least one (Renjifo et al., 2002). Thus, there are 25 species under some category of threat that have no populations in protected areas.

\section{Discussion}

Although birds are the best studied taxonomic group, detailed knowledge of geographic distributions of many species is still fragmentary (e.g. Beltrán \& Kattan, 2001), in particular concerning migrants. This is a limiting factor for assessing levels of representation of regional

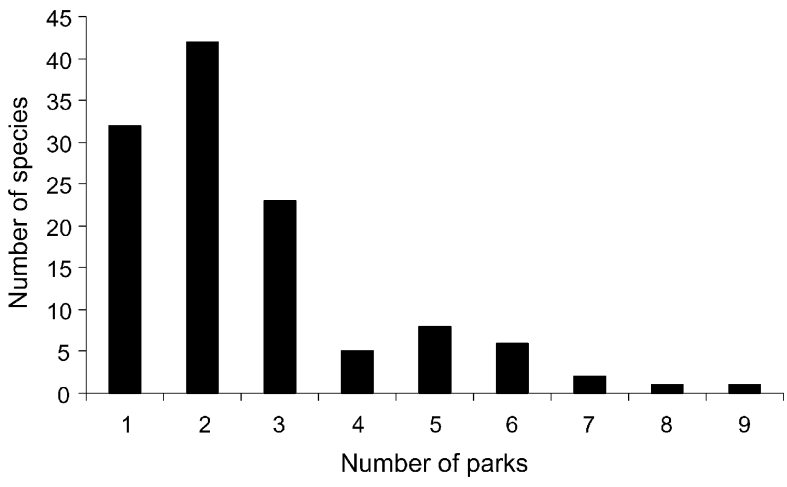

Fig. 3 Representation of threatened and near-threatened species in protected areas in the Colombian Andes.

Table 2 Percentage of potential bird species (and percentage of migratory birds in parentheses) recorded in protected areas occurring within each elevational zone of each subregion of the Colombian Andes.

\begin{tabular}{|c|c|c|c|c|c|c|c|c|}
\hline \multirow[b]{2}{*}{ Elevational zone $(\mathrm{m})$} & \multicolumn{2}{|c|}{ Western Cordillera } & \multicolumn{2}{|c|}{ Central Cordillera } & \multicolumn{2}{|c|}{ Eastern Cordillera } & \multirow{2}{*}{$\begin{array}{l}\text { Serranía de la } \\
\text { Macarena }\end{array}$} & \multirow{2}{*}{$\begin{array}{l}\text { Sierra Nevada } \\
\text { de Santa Marta }\end{array}$} \\
\hline & $\mathrm{W}$ versant & E versant & W versant & E versant & $\mathrm{W}$ versant & E versant & & \\
\hline $0-500$ & $69(55)$ & & & & & $15(23)$ & $73(55)$ & $88(69)$ \\
\hline $500-1,000$ & $73(56)$ & & & $44(66)$ & $4(3)$ & $24(23)$ & $66(55)$ & $88(69)$ \\
\hline $1,000-1,500$ & $79(61)$ & $73(54)$ & $71(71)$ & $54(69)$ & $6(3)$ & $36(25)$ & $60(55)$ & $87(70)$ \\
\hline $1,500-2,000$ & $80(58)$ & $78(56)$ & $80(73)$ & $67(72)$ & $12(3)$ & $42(25)$ & $52(54)$ & $87(72)$ \\
\hline $2,000-2,500$ & $77(58)$ & $79(58)$ & $88(75)$ & $79(74)$ & $19(4)$ & $48(24)$ & $55(58)$ & $87(70)$ \\
\hline $2,500-3,000$ & $67(56)$ & $83(56)$ & $93(73)$ & $93(73)$ & $27(4)$ & $50(24)$ & & $86(69)$ \\
\hline$>3,500$ & $55(38)$ & $85(64)$ & $98(93)$ & $99(92)$ & $44(29)$ & $58(27)$ & & $91(91)$ \\
\hline
\end{tabular}


biotas in protected areas. We found that the percentage of potential species actually recorded in reserves varied among subregions but could be as low as $14 \%$. On the other hand, representation increased with elevation, reflecting the fact that most protected areas are concentrated at upper elevations.

Some low representation values found in this study could simply reflect lack of knowledge, as vast areas within many of these protected areas have not been explored. In addition, few studies have been published. Only six of the references included in this study were published in national or international journals, with all other studies mostly in reports. Another source of error is that many studies were limited in time and spatial extent and may therefore underestimate species richness because of seasonal variation in species presence or detectability (G. Kattan et al., unpubl. data). Some species may only be detected after continued and intense sampling effort, even though they may be locally abundant (e.g. brown-banded antpitta Grallaria milleri; Kattan \& Beltrán, 1997, 1999). The disadvantages of short-term sampling are particularly relevant for transcontinental migratory species, which may be completely missed.

If all potential species actually occur in these protected areas then representation levels are high but this is unlikely as even well surveyed Parks (e.g. PNN Farallones de Cali) do not include all potential species. This reflects the fact that not all species are uniformly distributed over the entire subregion (Kattan et al., 2006). Some species are endemic to part of the subregion (e.g. Magdalena tinamou Crypturellus saltuarius) or have discontinuous distributions (e.g. chestnut-bellied flower-piercer Diglossa gloriosissima or red-ruffed fruitcrow Pyroderus scutatus, Hilty \& Brown, 1986; Renjifo et al., 2002; G. Kattan, pers. obs.). In physiographically complex regions such as the Andes differences in species composition may occur between neighbouring river drainages (Kattan et al., 2006).

In addition, the turnover in species composition among elevational zones means that protected areas that do not cover the entire altitudinal gradient will not adequately represent the slope's species diversity (Kattan \& Franco, 2004). In particular, the slopes of the inter-Andean valleys of the Cauca and Magdalena rivers have no protected areas at lower elevations. Some of the Critically Endangered and Endangered bird species in Colombia that do not occur in protected areas occur in the inter-Andean valleys and adjacent slopes (e.g. Magdalena tinamou, cinnamon teal Anas cyanoptera, Niceforo's wren Thryothorus nicefori and Tolima dove Leptotila conoveri; Appendix 2). The situation for these species is particularly critical because most of the original vegetation cover in this region has been destroyed (Etter, 1998). The high number of threatened species in the Andean region of Colombia reflects the degree of landscape transformation that this region has undergone, combined with an abundance of restricted range species (Bibby et al., 1992; Etter \& van Wyngaarden, 2000; Etter \& Villa, 2000). Other threatened species occur in areas entirely lacking official protection, such as the Serranía de San Lucas and adjacent lowlands on the northern tip of the central Cordillera (white-mantled barbet Capito hypoleucus, subtropical doradito Pseudocolopteryx acutipennis and Antioquia bristle-tyrant Phylloscartes lanyoni), northern end of the eastern Cordillera (Perijá metaltail Metallura iracunda), and the wetlands and dry enclaves of the Departments of Cundinamarca and Boyacá (yellowbilled pintail Anas georgica, spot-flanked gallinule Gallinula melanops and horned lark Eremophila alpestris).

Another aspect that needs to be considered in an evaluation of systems of protected areas is the viability of populations. There are two aspects to this problem: the number of populations and population size (determined by size of protected area). An important criterion in protected area planning is redundancy of populations, used as an insurance policy in case of catastrophic loss of one area (Groves, 2003). This is particularly relevant for threatened species, especially if populations are small and isolated. The mean area of National Parks in Andean Colombia is 178,176 ha and the largest is 629,280 ha (excluding Flora and Fauna Sanctuaries, which are all $<10,500$ ha). Although this may be sufficient for small-bodied and relatively sedentary species, many species require much larger areas and usually range beyond protected area boundaries, as is the case for large raptors (e.g. black-andchestnut eagle Oroaetus isidori). Many parks may not have sufficient area to sustain viable populations of these species (Thiollay, 1989). On the other hand, many species (e.g. parrots, quetzals) carry out regional or altitudinal migrations, and seasonal habitat and resources of critical importance may lack protection.

This study reveals that representation of bird species diversity in the Andean protected areas of Colombia is relatively high, but important gaps still exist, in particular relating to lower elevations and threatened species. Our findings suggest that representation of most species does not translate into coverage of threatened species, a result that complements other studies that have demonstrated that reserve selection based on threatened species does not guarantee coverage of all other species (Bonn et al., 2002, Tognelli, 2005). In addition, many protected areas are small and may not be sufficient for sustaining viable populations of many species. Even if the existing network of protected areas contains most bird species, not all bird species may be 
represented within their peak abundance locations (Bonn \& Gaston, 2005). Although in some cases representation levels exhibited by one taxa may reflect that of other groups (Warman et al., 2004), in other cases representation is expected to be much lower, in particular for less vagile taxonomic groups, and therefore the case of birds represents an optimistic scenario. More detailed analyses at the level of each protected area and subregion are required, taking into account regional and altitudinal distributions of species, to ensure that beta diversity within subregions is accounted for (Kattan et al., 2006). This is important because beta diversity not only represents differences in species composition, but also evolutionary phenomena.

\section{Acknowledgements}

We especially thank D. Cadena for gathering some of the bird inventories and contributing unpublished data. Other bird inventories were kindly shared with us by the Sociedad Antioqueña de Ornitología and Instituto de Investigación de Recursos Biológicos Alexander von Humboldt (M. Alvarez). Initial drafts of this paper were greatly improved by comments from M. Rios, C. Valderrama and two anonymous reviewers. Financial support was provided by the John D. and Catherine T. MacArthur Foundation.

\section{References}

Arango, N. (1998) Sistema de Parques Naturales nacionales. In Informe nacional sobre el estado de la biodiversidad 1997 Colombia, Tomo III. (eds M.E. Chávez \& N. Arango), pp. 12-20. Instituto de Investigación de Recursos Biológicos Alexander von Humboldt/Plan de las Naciones Unidas para el Medio Ambiente/Ministerio del Medio Ambiente, Bogotá, Colombia.

Arango, N., Armenteras, D., Castro, M., Gottsman, T., Hernández, O.L., Matallana, C.L., Morales, M., Naranjo, L.G., Renjifo, L.M., Trujillo, A.F. \& Villareal, H.F. (2003) Vacíos de conservación del Sistema de Parques Nacionales Naturales de Colombia desde una perspectiva ecoregional. WWF Colombia/ Instituto de Investigación de Recursos Biológicos Alexander von Humboldt, Bogotá, Colombia.

Beltrán, J.W. \& Kattan, G.H. (2001) First record of the slatybacked nightingale-thrush in the Central Andes of Colombia, with notes on its ecology and geographical variation. Wilson Bulletin, 113, 134-139.

Bibby, C.J., Collar, N.J., Crosby, M.J., Heath, M.F., Imboden, C., Johnson, T.H., Long, A.J., Stattersfield, A.J. \& Thirgood, S.J. (1992) Putting Biodiversity on the Map: Priority Areas for Global Conservation. International Council for Bird Preservation, Cambridge, UK.

Bonn, A. \& Gaston, K.J. (2005) Capturing biodiversity: selecting priority areas for conservation using different criteria. Biodiversity and Conservation, 14, 1083-1100.
Bonn, A., Rodrigues, A.S.L. \& Gaston, K.J. (2002) Threatened and endemic species: are they good indicators of patterns of biodiversity on a national scale? Ecology Letters, 5, 733-741.

Bürgl, H. (1961) Historia Geológica de Colombia. Revista de la Academia Colombiana de Ciencias Exactas, Físicas y Naturales, 11, 137-191.

Cadena, A., Alvarez, M., Parra, J.L., Jiménez, I., Mejìa, C.A., Santamaría, M., Franco, A.M., Botero, C.A., Mejìa, G.D. Umaña, A.M., Calixto, A., Aldana, J. \& Londoño, G.A. (2000) The birds of CIEM, Tinigua National Park, Colombia: an overview of 13 years of ornithological research. Cotinga, 13, 46-54.

Calderon, J.J. (1998) Ecologia de comunidades aviarias en paramos del suroccidente colombiano. BSc thesis, Universidad del Valle, Cali, Colombia.

Canaday, R.L. (1986) Aves encontradas en el sector Orocúe del Parque Nacional Natural Tamá, Norte de Santander. Inderena, Bogotá, Colombia.

CARDER (Corporación Autónoma Regional de Risaralda) (1994) Lista de aves del Parque Regional Ucumarì. Cedro Negro, 13, 1-4.

Echeverry, H. (1986) Avifauna parcial del Parque Nacional Natural Las Orquideas. Inderena, Medellin, Colombia.

Etter, A. (1998) Mapa general de ecosistemas de Colombia. Map in Informe nacional sobre el estado de la biodiversidad 1997 Colombia, Tomo I (eds M.E. Chavez \& N. Arango), pp. 19-21. Instituto de Investigación de Recursos Biológicos Alexander von Humboldt/Plan de las Naciones Unidas para el Medio Ambiente/Ministerio del Medio Ambiente, Bogotá, Colombia.

Etter, A. \& van Wyngaarden, W. (2000) Patterns of landscape transformation in Colombia, with emphasis in the Andean region. Ambio, 29, 432-439.

Etter, A. \& Villa, L.A. (2000) Andean forests and farming systems in part of the Eastern Cordillera (Colombia). Mountain Research and Development, 20, 236-243.

Groves, C.R. (2003) Drafting a Conservation Blueprint. A Practitioner's Guide to Planning for Biodiversity. Island Press, Washington, DC, USA.

Hernández-Camacho, J., Hurtado, A., Ortiz, R. \& Walshburger, T. (1992) Unidades biogeográficas de Colombia. In La diversidad biológica de Iberoamérica I (ed. G. Halffter), pp. 105-173. Acta Zoológica Mexicana, volumen especial, Mexico DF, Mexico).

Hilty, S.L. (1997) Seasonal bird movements in Colombia. Ornithological Monographs, 48, 321-343.

Hilty, S.L. \& Brown, W.L. (1985) A Guide to the Birds of Colombia. Princeton University Press, Princeton, USA

Hilty, S.L. \& Silliman, J.R. (1983) Puracé National Park, Colombia. American Birds, 37, 247-256.

IUCN (2001) 2001 Categories and Criteria (version 3.1). IUCN, Gland, Switzerland [http://www.redlist.org/info/ categories_criteria2001.html, accessed 18 October 2006].

Irving, E.M. (1975) Structural Evolution of the Northernmost Andes, Colombia. US Geological Survey, Washington, DC, USA.

Kattan, G.H. \& Beltrán, J.W. (1997) Rediscovery and status of the brown-banded antpitta Grallaria milleri in the central Andes of Colombia. Bird Conservation International, 7, 367-371.

Kattan, G.H. \& Beltrán, J.W. (1999) Altitudinal distribution, habitat use and abundance of Grallaria antpittas in the Central Andes of Colombia. Bird Conservation International, 9, 271-281. 
Kattan, G.H. \& Franco, P. (2004) Bird diversity along elevational gradients in the Andes of Colombia: area and mass effects. Global Ecology and Biogeography, 13, 451-458.

Kattan, G.H., Franco, P., Rojas, V. \& Morales, G. (2004) Biological diversification in a complex region: a spatial analysis of faunistic diversity and biogeography of the Andes of Colombia. Journal of Biogeography, 31, 1829-1839.

Kattan, G.H., Franco, P., Saavedra, C.A., Valderrama, C., Rojas, V., Osorio, D. \& Martínez, J. (2006) Spatial components of bird diversity in the Andes of Colombia: implications for designing a regional reserve system. Conservation Biology, 20, 1204-1211.

McNeely, J.A., Miller, K.R., Reid, W.V., Mittermier, R.A. \& Werner, T.B. (1990) Conserving the World's Biological Diversity. IUCN, Gland, Switzerland.

Myers, N., Miterrmeier, R.A., Mittermier, C.G., da Fonseca, G.A.B. \& Kent, J. (2000) Biodiversity hotspots for conservation priorities. Nature, 403, 853-858.

Naranjo, L.G. (1994) Composición y estructura de la avifauna del Parque Regional Ucumarí. In Ucumarí, un caso típico de la diversidad biótica andina (ed. J.O. Rangel), pp. 305-325. Corporación Autónoma Regional de Risaralda, Pereira, Colombia.

Negret, A.J. (1994) Lista de aves registradas en el Parque Nacional Natural Munchique, Cauca. Novedades Colombianas, 6, 69-83.

Olivares, A. (1973) Aves de la Sierra Nevada del Cocuy, Colombia. Revista de la Academia Colombiana de Ciencias Exactas, Físicasô yô Naturales, 14, 39-48.

Orejuela, J.E. (undated) Guía de pieles. Aves del Parque Nacional Natural Los Nevados. Inderena, Bogotá, Colombia.

Orme, C.D., Davies, R.G., Burgess, M., Eigenbrod, F., Pickup, N., Olson, V.A., Webster, A.J., Ding, T., Rasmussen, P.C., Ridgely, R.S., Stattersfield, A.J., Bennett, P.M., Blackburn, T.M., Gaston, K.J. \& Owens, I.P.F. (2005) Global hotspots of species richness are not congruent with endemism or threat. Nature, 436, 1016-1019.

Pfeifer, A.M., Verhelst, J.C. \& Botero, J.E. (2001) Estado de conservación de las aves del Parque Nacional Natural Los Nevados y su zona de amortiguación. Boletín SAO, 12, 21-41.

Pressey, R.L. (1994) Ad hoc reservations: forward or backward steps in developing representative reserve systems. Conservation Biology, 8, 662-668.

Renjifo, L.M., Franco-Maya, A.M., Amaya-Espinel, J.D., Kattan, G.H. \& López-Lanús, B. (eds) (2002) Libro rojo de aves de Colombia. Serie Libros Rojos de Especies Amenazadas de Colombia, Instituto de Investigación de Recursos Biológicos Alexander von Humboldt/Ministerio del Medio Ambiente, Bogotá, Colombia.

Renjifo, L.M., Servat, G.P., Goerck, J.M., Loiselle, B.A. \& Blake, J.G. (1997) Patterns of species composition and endemism in the northern Neotropics: a case for conservation of montane avifaunas. Ornithological Monographs, 48, 577-594.
Rodrígues, A.S.L., Akcakaya, H.R., Andelman, S.J., Bakarr, M.I., Boitani, L., Brooks, T.M., Chanson, J.S., Fishpool, L.D.C., da Fonseca, G.A.B., Gaston, K.J., Hoffman, M., Marquet, P.A., Pilgrim, J.D., Pressey, R.L., Schipper, J., Sechrest, W., Stuart, S.N., Underhill, L.G., Waller, R.W., Watts, M.E.J. \& Yan, X. (2004) Global Gap Analysis: priority regions for expanding the global protected-area network. Bioscience, 54, 1092-1100.

Sarria, S. (1991) Parque Natural Nacional Las Hermosas. Corporación Autónoma Regional del Valle del Cauca Corporación Autónoma Regional del Tolima, Cali, Colombia.

Sarria, S. (1993) Parque Nacional Natural Farallones de Cali, Monografía. Corporación Autónoma Regional del Valle del Cauca - Procuencas, Palmira, Colombia.

Stattersfield, A.J., Crosby, M.J., Long, A.J. \& Wege, D.C. (1998) Endemic Bird Areas of the World: Priorities for Biodiversity Conservation. Birdlife International, Cambridge, UK.

Stotz, D.F., Fitzpatrick, J.W., Parker, T.A. \& Moskovitz, D.K. (1996) Neotropical Birds: Ecology and Conservation. Chicago University Press, Chicago, USA.

Thiollay, J.M. (1989) Area requirements for the conservation of rain forest raptors and game birds in French Guiana. Conservation Biology, 3, 128-137.

Tognelli, M.F. (2005) Assessing the utility of indicator groups for the conservation of South American terrestrial mammals. Biological Conservation, 121, 409-417.

Warman, L.D., Forsyth, D.M., Sinclair, A.R.E., Freemark, K., Moore, H.D., Barrett, T.W., Pressey, R.L. \& White, D. (2004) Species distributions, surrogacy, and important conservation regions in Canada. Ecology Letters, 7, 374-379.

\section{Appendices 1-2}

The appendices for this article are available online at http://journals.cambridge.org

\section{Biographical sketches}

Padu Franco and Carlos A. Saavedra are researchers at the Colombia Program of the Wildlife Conservation Society (WCS). Their work focuses on macroecology and behavioural ecology of tropical birds, and the ecology and conservation of mammals, respectively.

Gustavo Kattan is the coordinator of the Colombia Program of the WCS. His interests focus on the conservation of Andean ecosystems, and he conducts research on macroecology, community ecology and population biology of threatened species. 